\title{
Índice del Número 11
}

Temática: Políticas de reconocimiento de la agencia y participación desde el inicio de la vida.

\section{Páginas Preliminares}

Presentación general del número

Norma Alicia Del Río Lugo

Pág. 1-4

Reconocimiento a los evaluadores del número 10

Pág. 5

Graciela Tonon

\section{Sección Artículos}

La construcción del "niño como sujeto de derechos" y la agencia infantil en cuestión

Gabriela Paula Magistris

Estudiantes Sordos señantes: un botón de muestra de la importancia de participar desde la infancia

Miriam Viridiana Verástegui Juárez

Ser niña, indígena y migrante. Curso de vida y agencia en contextos sociales signados por la violencia de género y la desigualdad. El caso de una niña tsotsil originaria de los Altos de Chiapas

Sarai Miranda

De piedras a flores: experiencia de participación infantil a través del arte en un tianguis del Estado de México

Pág. 6-28

Freya Castro Pimentel

Derecho de participación en contextos de cuidado y protección

Gloria Marina López, Magaly Rafaela Couret, Yuherqui Ayari Guaimaro

Pág. 29-51

Pág. 52-73

La maternidad como proyecto individual y autónomo. El caso de las madres solas por elección

Pág. 130-147

María Laura Giallorenzi

La gobernabilidad de los servicios de agua y saneamiento y los conflictos por el agua en América Latina

Melisa Orta

Pág. 97-129

\section{Sección Política Internacional}

Introducción a la Sección Política Internacional

Lía Rodríguez de la Vega

Pág. 171-173

La relación India-Argentina en clave estratégica

Pág. 174-178

Raúl Rishi Verma

Los desafíos del futuro: crecimiento poblacional y desarrollo María Emilia Burgos 


\section{Sección Aportes de Estudiantes}

Introducción a la Sección Aportes de Estudiantes Yussef Becher

Pág. 186-187

La discapacidad bajo la lupa de los derechos humanos

Pág. 188-192

Florencia Buscarolo

Mujeres y estructuras patriarcales: el papel de los movimientos

Pág. 193-197 feministas

Aldana Florencia Romano

\section{Sección Reseña y Rescate de Libros}

Introducción a la Sección Reseña y Rescate de Libros Daniel Del Percio

Pág. 198

La participación adolescente. Deconstruyendo el adultocentrismo

Pág. 199-203 Celsa Garcia Pozo

Juegos de chicos, problemas de grandes

Pág. 204-208 María Lucía Puppo

Rescate: Reflexiones en torno a la asombrosa complejidad de lo humano Norma Alicia del Rio Lugo

Pág. 209-213 